\title{
DOES INTRINSIC RELIGIOSITY MODERATE BETWEEN THE SELF- ASSESSMENT SYSTEM AND TAX EVASION? A RESEARCH-BASED ON GENDER
}

\author{
Alfriadi Dwi Atmoko* \\ Universitas Amikom Yogyakarta \\ Ring Road Utara St., Sleman \\ Indonesia 55281 \\ alfriadiatmoko@amikom.ac.id
}

\begin{abstract}
This study aims to examine the effect of the self-assessment system on tax evasion and the effect of intrinsic religiosity moderation on the relationship between the self-assessment system and tax evasion. This study also differences in the influence of gender on the effect of the self-assessment system on tax evasion. This research method uses moderated regression analysis (MRA) and an independent sample $t-$ test. The results show that the self-assessment system had a negative effect on tax evasion. Meanwhile, intrinsic religiosity does not moderate the relationship between the self-assessment system and tax evasion. There are no gender differences at the level of the selfassessment system, intrinsic religiosity, and tax evasion.
\end{abstract}

Keywords: Self-Assessment System; Intrinsic Religiosity; Gender; Tax evasion

\section{ABSTRAK}

Penelitian ini bertujuan untuk menguji pengaruh self-assessment system terhadap tax evasion dan efek moderasi religius intrinsik pada hubungan self-assessment system dengan tax evasion. Penelitian ini juga menganalisis perbedaan gender pada tingkat self-assessment system, religius intrinsik dan tax evasion. Metode penelitian ini menggunakan analisis moderated regression analysis (MRA) dan independent sample t-test. Hasil penelitian menunjukkan bahwa self-assessment system berpengaruh negatif terhadap tax evasion. Religius intrinsik tidak memoderasi hubungan self-ssessment system dengan tax evasion. Tidak terdapat perbedaan gender pada tingkat self-assessment system, religius intrinsik dan tax evasion.

Kata Kunci :

JEL Classification:
Self-Assessment System; Religious Intrinsik; Gender; Tax Evasion

D91; $\mathrm{H} 26$

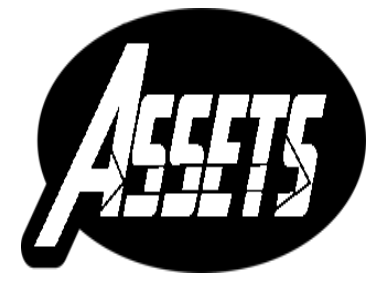

ASSETS

Jurnal Akuntansi dan Pendidikan

Vol. 10 No. 2

Page 123-131

Madiun, October 2021 p-ISSN: 2302-6251 e-ISSN: 2477-4995

Article History Submitted: September 9, 2019 Accepted: July 16, 2021 


\section{INTRODUCTION}

According to news regarding state revenue, tax is the most significant revenue in Indonesia (Badan Pusat Statistik, 2019). The government still relies on taxes in the revenues used to finance infrastructure in Indonesia. Other state revenues are non-tax state revenues and grant receipts. State revenue is allocated for financings in Indonesia, such as education, health, agriculture, and other vital fields. The tax reporting system in Indonesia is made more accessible to taxpayers voluntarily reporting their income. The reporting in question is that Taxpayers do not have to come and queue at the Tax Office because the government wants to provide the best service to Taxpayers. Data on State revenues can be seen in Table 1.

Table 1. State Revenue

\begin{tabular}{llrrrr}
\hline & Source of Acceptance & \multicolumn{1}{c}{2016} & \multicolumn{1}{c}{2017} & \multicolumn{1}{c}{2018} & \multicolumn{1}{c}{2019} \\
\hline 1 & Tax Revenue & $1.284 .970,10$ & $1.343 .529,80$ & $1.518 .789,80$ & $1.643 .083,90$ \\
2 & Non-tax revenue & $261.976,30$ & $311.216,30$ & $409.320,20$ & $386.333,90$ \\
3 & Grant & $8.987,70$ & $11.629,80$ & $15.564,90$ & $1.340,00$ \\
& total & $1.555 .934,20$ & $1.666 .375,90$ & $1.943 .674,90$ & $2.030 .757,80$ \\
\hline
\end{tabular}

Source: Badan Pusat Statistik (2019)

Atmoko (2018) said that clearly, the law regulates the taxation procedures. The regulation was made to ensure that people in Indonesia obey and are aware of the procedures for paying taxes and do not carry out tax evasion. Tax evasion, in general, is the act of taxpayers not reporting actual income and even not reporting their income at all to get a low tax burden. The difference in accounting and financial reporting is also one indicator of the community doing tax planning to avoid high taxes. State revenue data from the tax sector shows a decrease in the tax ratio of central taxes plus natural resource revenue (SDA) to gross domestic income (GDP) at a price. The 2015 tax ratio showed $11.6 \%$ and decreased to $10.8 \%$ in 2016 and $10.7 \%$ in 2017, which can be seen in Table 2 as follows.

Table 2. Indonesia Tax Ratio 2015-2017

\begin{tabular}{clrrr}
\hline \multirow{2}{*}{ No. } & \multicolumn{1}{c}{ Information } & \multicolumn{1}{c}{ Year } \\
& & \multicolumn{1}{c}{ 11.526,33 } & \multicolumn{1}{c}{2016} & \multicolumn{1}{c}{$12.406,77$} \\
\hline 1 & GDP by Price (Trillion) & $1.240,42$ & $1.284,97$ & $13.588,8$ \\
2 & Central Tax (Trillion) & 95,85 & 59,85 & $1.343,53$ \\
3 & SDA Revenue (Trillion) & 78,17 & 44,09 & 81,84 \\
& Oil and Gas & 17,68 & 15,76 & 23,76 \\
& Mining & $11,6 \%$ & $10,8 \%$ & $10,7 \%$ \\
\hline
\end{tabular}

Source: DJP (2018)

Suwandhi (2010), Puspitasari \& Wardani (2013), and Mira (2016) states that the self-assessment system has a negative effect on tax evasion (tax evasion). The same thing was found in Purwanto, Sulaeha, and Safira (2018), which states that the selfassessment system has a negative effect on tax evasion. It means in implementing the self-assessment system where the higher the level of truth in calculating, the accuracy of depositing and filling in and reporting the taxpayer's annual notification letter, the lower the level of tax evasion. In other words, if the self-assessment system is appropriately implemented and sincerity and honesty both from the tax authorities 
and taxpayers, the higher taxpayer compliance in fulfilling tax obligations. However, Friskianti \& Handayani (2014) shows that the self-assessment system does not affect tax evasion.

There is a religiosity factor in humans, namely religiosity from within (intrinsic) and religiosity from the outside (extrinsic). In general, intrinsic religiosity can be said that human behavior is reflected in the human being according to his conscience. In contrast, extrinsic religiosity is human action and action reflected in his actual or visible behavior. Religiosity is related to the values or philosophy possessed by a person related to the religiosity he believes in (Budiarto, Yennisa \& Nurmalisa, 2017). According to Mokhlis (2009) and Fauzan (2015), religiosity is a universal form of belief and significantly influences attitudes, values, and behavior both at the individual and community levels. Basri (2015) states that all religiosity generally has the same goal of controlling good behavior and inhibiting lousy behavior. Budiarto, Yennisa \& Nurmalisa (2017) stated that the lower the religiosity level of a person, the more likely it is to tax evasion. Ismail (2012) explained that people who have intrinsic religiosity make religiosity a motivation to live, live consistently morally, are responsible for their fellow human beings and God. Their life is valuable and apart from seeking the truth. People who have a high intrinsic religiosity spirit will behave honestly and responsibly to pay their taxes as much as their obligations consciously.

In general, gender is the difference between a person based on gender. According to Budiarto, Yennisa, and Nurmalisa (2017), the ethical behavior of men is lower than that of women. Most men are more willing to take risks and do everything they can to achieve their desires. In the case of tax evasion, men do more tax evasion than women (Dharma, Agusti \& Kurnia, 2016). Atmoko (2018) found that male gender interactions are more significant than female gender interactions in the relationship between money ethics and tax evasion. Budiarto, Yennisa \& Nurmalisa (2017) also found a similar fact. Namely, there are differences in the influence of men and women on tax evasion.

The difference between this study and previous research is to see the differences in each variable from a gender perspective, in this study using the Theory of Reasoned Action (TRA), which was coined by Fishbein \& Ajzen (1975) which explains that humans behave consciously and consider all available information. Therefore, this study uses gender perception to determine the differences in the self-assessment system, intrinsic religiosity, and tax evasion. The previous research conducted by Budiarto, Yennisa, \& Widiyaningrum (2018) discussed gender, love of money, religiosity, and tax evasion. Budiarto, Yennisa \& Nurmalisa (2017) discussed gender of religiosity, machiavellian, and tax evasion. This study used the variables of the selfassessment system, intrinsic religiosity, and tax evasion. The results of this study are expected to contribute to future research references and confirm the research carried out by Budiarto, Yennisa \& Widiyaningrum (2018) and Budiarto Yennisa \& Nurmalisa (2017).

\section{METHOD}

The population in this study were taxpayers who were in Yogyakarta. Samples taken are taxpayers who have reported their taxes using the self-assessment system. The data source in this study is primary data from questionnaires distributed to taxpayers in the Special Region of Yogyakarta. The research sample was taken by a simple random sampling method. Simple random sampling was chosen because this sampling technique is the easiest to do and only involves one predetermined random voter. The questions from this questionnaire develop a questionnaire that has been

This work is licensed under a Creative Commons Attribution-ShareAlike 4.0 International License. 
used by Friskianti \& Handayani (2014), as well Sari (2015) for self-assessment system variable, Basri (2014), and Budiarto, Yennisa \& Nurmalisa (2017) for intrinsic religiosity variable because it has been tested for validity and reliability. This study also modified the questions to make them simpler and easier to understand by respondents so that they are expected to contribute to future research.

The questionnaires were distributed using personally administered questionnaires and electronically using a google form. The type of question in the questionnaire is a close question that asks the respondent to choose one of the answers provided using a cross or a circle or clicking (if done electronically) on the selected answer option. Close questions help respondents make decisions quickly to choose between several alternative answers. In addition to close questions, the questionnaire also contains classification data or what is known as personal information or demographic questions that contain gender information, such as age, education level, job position, and ownership of a taxpayer identification number (NPWP).

The analysis model used to test the estimated direct and moderating effects is the Moderated Regression Analysis (MRA) analysis model using the SPSS application. Meanwhile, to test the differences in the level of self-assessment system, intrinsic religiosity, and tax evasion based on gender using the independent sample t-test.

The self-assessment system is one of the collection systems in taxation, which gives full authority to the taxpayer to calculate, deposit and report their tax obligations. The instruments in this study used instruments that have been used by Friskianti \& Handayani (2014) and Sari (2015) with 8 question items and measurements with a 5 point Likert scale. Point 1 indicates strongly disagree and point five indicates strongly agree.

Intrinsic religiosity is the belief of an individual who is responsible for his God. The instruments in this study used instruments that have been developed by Basri (2014) with 8 question items and measurements with a 5 point Likert scale. Point 1 indicates strongly disagree and point five indicates strongly agree.

Tax evasion is an act of tax evasion illegally by deliberately not reporting its obligations correctly. The instruments in this study used instruments that have been developed by Basri (2014) and Budiarto, Yennisa \& Nurmalisa (2017) with 10 question items and measurements with a 5 point Likert scale. Point 1 indicates strongly disagree and point five indicates strongly agree.

\section{RESULT AND DISCUSSION}

The validity test in this study uses factor analysis with the principle of correlation. The validity test results on this research instrument contained five invalid question items, so the five items were discarded in the next test. After removing the five-question items, the value of the loading factor in the validity test increases, and the data can be used for the next test.

The reliability test shows the degree of freedom of measurement bias or error (Sekaran, 2006). The method used to test the reliability is to calculate Cronbach's coefficient alpha. The reliability test results in this study all data proved reliable with Cronbach's coefficient alpha $>0,7$ so that the data used has been tested for reliability.

Table 3 shows that the number of samples obtained was 109 respondents. The 109 samples obtained showed that as many as 49 male respondents and 65 female respondents. Most respondents' age was 31-40 years old with a percentage rate of $56 \%$. Respondents' education was dominated by an S1 education level with a total of 76 respondents and a percentage level of $69.8 \%$. The job position of most respondents is a 
company staff with a total of 58 respondents, and the percentage level is $53.2 \%$. All respondents have an NPWP.

\section{Table 3. Descriptive Statistics}

\begin{tabular}{|c|c|c|}
\hline Characteristics of Respondents & Amount & Percentage \\
\hline \multicolumn{3}{|l|}{ Gender } \\
\hline Man & 49 & 45 \\
\hline Women & 60 & 55 \\
\hline Total & 109 & 100 \\
\hline \multicolumn{3}{|l|}{ Age } \\
\hline 20-30 years & 24 & 22 \\
\hline $31-40$ years & 61 & 56 \\
\hline $41-50$ years & 14 & 12.8 \\
\hline$>51$ years & 10 & 9,2 \\
\hline Total & 109 & 100 \\
\hline \multicolumn{3}{|l|}{ Last education } \\
\hline D3 & 19 & 17.4 \\
\hline S1 & 76 & 69.8 \\
\hline S2 and S3 & 14 & 12.8 \\
\hline Total & 109 & 100 \\
\hline \multicolumn{3}{|l|}{ Job Position } \\
\hline Owner & 36 & 33 \\
\hline Manager & 15 & 13.8 \\
\hline Staff & 58 & 53.2 \\
\hline Total & 109 & 100 \\
\hline \multicolumn{3}{|l|}{ Ownership of NPWP } \\
\hline Yes & 109 & 100 \\
\hline Not & 0 & 0 \\
\hline Total & 109 & 100 \\
\hline
\end{tabular}

Table 4. Moderated Regression Analysis Test

\begin{tabular}{|c|c|c|c|c|c|c|}
\hline \multirow{2}{*}{\multicolumn{2}{|c|}{ Model }} & Unstandardizeo & Coefficients & \multirow{2}{*}{$\begin{array}{c}\text { Standardized } \\
\text { Coefficients } \\
\text { Beta }\end{array}$} & \multirow[t]{2}{*}{$\mathrm{t}$} & \multirow[t]{2}{*}{ Sig. } \\
\hline & & B & Std. Error & & & \\
\hline \multirow[t]{3}{*}{1} & (Constant) & 4.082 & 0,441 & & 9.260 & 0,000 \\
\hline & SS & -453 & 0,212 & -358 & -2.131 & 0,035 \\
\hline & $\mathrm{IR} * \mathrm{SS}$ & $-0,033$ & 0,038 & -148 & -880 & 0,381 \\
\hline
\end{tabular}

Dependent: TE

Information:

$\mathrm{SS}=$ Self-Assessment System

IR * SS = moderation Intrinsic Religiosity * Self-Assessment System

$\mathrm{TE}=$ Tax Evasion

Based on Table 4, the self-assessment system has a negative effect on tax evasion. The results of this study are in line with Suwandhi (2010), Puspitasari \& Wardani 
(2013), Mira (2016), and Purwanto, Sulaeha \& Safira (2018), which shows that the implementation of the self-assessment system has a significant negative effect on tax evasion. The higher the level of taxpayers' understanding of the self-assessment system, the lower the level of tax evasion. The self-assessment system makes it easier for people to calculate, collect, deduct and report their tax obligations. This convenience has been made easier by the government by launching a website www.djponline.pajak.go.id, an e-filing system to report taxes online and in real-time via the internet. Tax reporting can be done anywhere as long as it is connected to an internet network. Therefore, the ease of tax reporting has increased the interest of taxpayers to report their tax obligations, but it has excellent potential for taxpayers to commit tax evasion. Self-assessment system demands voluntary compliance from taxpayers, has the potential for taxpayers to commit fraudulent actions, manipulate the calculation of the amount of taxes, tax evasion (Rahayu, 2013)

Based on Table 4 above, intrinsic religiosity does not moderate the relationship between the self-assessment system and tax evasion. Based on planned behavior theory put forward by Fishbein \& Ajzen (1975) that a person's intention to carry out specific actions is caused by two reasons, namely subjective norms, and attitudes towards behavior. According to Ajzen (1988), subjective norms are perceptions of social pressure to do or not take action. The self-assessment system that has been regulated by law is a rule that every taxpayer must obey. The actions taken by the taxpayers relating to the self-assessment system make the taxpayer comply with the law and not carry out tax evasion. The tax collection system using the self-assessment system has been regulated in law. The intrinsic religiosity factor cannot moderate the relationship between the self-assessment system and tax evasion. The absence of a strong belief (faith or intrinsic religiosity) will increase the awareness of taxpayers in paying taxes and the absence of good morals and ethics that can support the self-assessment system (Yunus, Bulutoding, \& Umar, 2020). Therefore, intrinsic religiosity cannot strengthen or weaken the self-assessment system that has been established following statutory regulations.

Table 5. Independent Sample T-Test

\begin{tabular}{|c|c|c|c|c|c|c|c|}
\hline \multirow{2}{*}{ Variable } & \multicolumn{2}{|c|}{ Women } & \multicolumn{2}{|c|}{ Man } & \multirow{2}{*}{$\begin{array}{c}\text { Lavene's }^{\text {Test }} \\
\end{array}$} & \multirow{2}{*}{ Sig. } & \multirow{2}{*}{ Conclusion } \\
\hline & Mean & Std. Dev & Mean & Std. Dev & & & \\
\hline SS & 4,0339 & 0,58161 & 3,8869 & 0,455998 & 0,071 & 0,175 & $\begin{array}{l}\text { There is no } \\
\text { difference }\end{array}$ \\
\hline IR & 4,1398 & 0,544904 & 4,09226 & 0,452853 & 0,097 & 0,644 & $\begin{array}{l}\text { There is no } \\
\text { difference }\end{array}$ \\
\hline $\mathrm{TE}$ & 1,6847 & 0,842167 & 1,77143 & 0,669286 & 0,062 & 0,581 & $\begin{array}{l}\text { There is no } \\
\text { difference }\end{array}$ \\
\hline
\end{tabular}

Information:

SS = Self-Assessment System

IR = Intrinsic Religiosity

$\mathrm{TE}=\mathrm{Tax}$ Evasion

In Table 5, there is no difference in the level of the self-assessment system based on gender. It is probably because the level of education in this sample is that of taxpayers who have a high level of education. The understanding of taxpayers about the self-assessment system does not differ between men and women because it is regulated by law. Everyone has the same opportunity to calculate, report, and deposit their taxes to the state because the self-assessment system has been established as a tax 
reporting system for taxpayers. According to the planned behavior theory Fishbein \& Ajzen (1975), the self-assessment system is not social pressure, and every taxpayer must report their tax obligations. Therefore there is no difference in the level of the selfassessment system based on gender.

In Table 5, these results align with Budiarto, Yennisa \& Nurmalisa (2017), which states that there is no difference in the level of religiosity (intrinsic and extrinsic) based on gender. Intrinsic religiosity cannot be seen with the naked eye because only the individual can measure his religiosity level. In the sample proposed in this study, there is also no mention of the respondent's religiosity in gender. Therefore there is no difference in the level of intrinsic religiosity based on gender.

The higher education level can cause someone to realize that taking tax evasion is an act that violates the law so that someone tends to report their tax obligations following statutory provisions. Therefore there is no difference in tax evasion rates based on gender. Meanwhile, according to Westbrook, Arendall \& Padelford (2011), men and women alike find some of the same actions in behavior. Both men and women have the same opportunity to do tax evasion. Therefore there is no difference in tax evasion rates based on gender.

\section{CONCLUSION}

Based on the results of the tests carried out, it can be concluded that the selfassessment system has a negative effect on tax evasion. Intrinsic religiosity does not moderate the relationship between the self-assessment system and tax evasion. The tax reporting system carried out by the taxpayer itself has nothing to do with intrinsic religiosity factors because the system has been regulated in law so that intrinsic religiosity cannot strengthen or weaken the self-assessment system. There is no difference in influence on the level of self-assessment system, intrinsic religiosity, and tax evasion based on gender.

There are several limitations of this study. First, it only uses the independent variable self-assessment system to focus on the tax collection system, even though many other variables are thought to affect tax evasion. For example, such as the machiavellian variable carried out by Budiarto, Yennisa \& Nurmalisa (2017), love of money made by Basri (2015) and Dewanta \& Machmuddah (2019). Second, the characteristics of the sample in this study were taxpayers with a reasonably high level of education, so their understanding of the self-assessment system and tax evasion was good. Therefore, the allegations related to differences in the level of self-assessment systems and tax evasion based on gender are not proven. Third, demographic data to measure intrinsic religiosity does not provide information about a person's belief (religiosity), so that the presumption of differences in intrinsic religiosity levels based on gender is not proven. Fourth, research instruments for measuring tax evasion are invalid when given to taxpayers with highly educated characteristics.

Suggestions that can be put forward for future research are: first because based on this research, it is evident that the higher the level of taxpayers understanding of the self-assessment system, the lower the level of tax evasion, it is essential for the Directorate General of Taxes to continue to provide intensive socialization about selfassessment system, including the latest system update that makes the tax reporting process more accessible. With these efforts, it is hoped that the self-assessment system program will be evenly distributed to all taxpayers with various educational backgrounds. The self-assessment system is a tax calculation and reporting system carried out by the taxpayers themselves to make it easier for taxpayers to determine the 
obligations that must be reported to the state but prone to tax evasion. Therefore, it is necessary to provide oversight of this system, such as attaching salary slips, assets registered in the taxpayer's name, bank accounts, and tax reports that third parties have withheld. Second, further research can add independent variables such as variables machiavellian, which are conducted by Budiarto, Yennisa, \& Nurmalisa (2017), love of money made by Basri (2015), Dewanta and Machmuddah (2019), a tax audit conducted by Mira (2016), and understanding of taxes carried out by Dharma (2016) so that it is expected to get more accurate results about the factors that can affect the tax evasion. Third, increase the number of samples related to the level of education and religiosity on demographic data to obtain a more accurate variation of results in future testing.

\section{REFERENCES}

Ajzen, I. (1988). Attitudes, Personality, and Behavior. Milton Keynes, UK: Open University Press.

Atmoko, A. D. (2018). Efek Interaksi Religiusitas Intrinsik dan Gender pada Hubungan Money Ethics dengan Tax Badan Pusat Statistik Evasion. Jurnal Riset Akuntansi Dan Keuangan, 6(3), 391-404.

Badan Pusat Statistik. (2020). Pendapatan Nasional Indonesia 2015-2019. Retrieved 29 Oktober 2019,

from https://www.bps.go.id/publication/2020/06/12/7fe8d749c43bad46b1601662/p endapatan-nasional-indonesia-2015-2019.html.

Basri, Y. M. (2014). Efek moderasi religuisitas dan gender terhadap hubungan etika uang. Sna 17, 1-23.

Basri, Y. M. (2015). Pengaruh gender, religiusitas dan sikap love of money pada persepsi etika penggelapan pajak. Jurnal Ilmiah Akuntansi Dan Bisnis, 10(1), 4554 .

Budiarto, D. S., Yennisa, \& Nurmalisa, F. (2017). Hubungan Antara Religiusitas dan Machiavellian dengan Tax Evasion: Riset Berdasarkan Perspektif Gender. Telaah Bisnis, 18(1), 19-32.

Budiarto, D. S., Yennisa, \& Widiyaningrum, R. (2018). Does Religiosity Improve Tax Compliance? An Empirical Research Based From Gender. Jurnal Dinamika Akuntansi, 10(1), 82-90.

Dewanta, M. A., \& Machmuddah, Z. (2019). Gender, Religiosity, Love of Money, and Ethical Perception of Tax Evasion. Jurnal Dinamika Akuntansi Dan Bisnis, 6(1), 71-84. https://doi.org/10.24815/jdab.v6i1.10990

Dharma, L., Agusti, R., \& Kurnia, P. (2016). Pengaruh Gender, Pemahaman Perpajakan dan Religiusitas terhadap Persepsi Penggelapan Pajak. Jurnal Online Mahasiswa Fakultas Ekonomi Universitas Riau, 3(1), 1565-1578.

DJP. (2018). Rasio Pajak (Tax Ratio) dari Masa ke Masa. Retrieved 29 Oktober 2019, from https:/ / www.pajak.go.id/id/86-rasio-pajak-tax-ratio-dari-masa-ke-masa.

Fauzan, F. (2015). Pengaruh Religiuistas dan Ethical Climate terhadap Ethical Behavior. Jurnal Ekonomi Modernisasi, 11(3), 187-202.

Fishbein, M., \& Ajzen, I. (1975). Belief, Attitude,Intention and Behaviour. Reading, Mass: Addison-Wesley.

Friskianti, Y., \& Handayani, B. D. (2014). Pengaruh Self-assessment System, Keadilan, Teknologi, Perpajakan dan Ketidakpercayaan Kepada Pihak Fiskus Terhadap Tindakan Tax Evasion. Accounting Analysis Journal, 3(4).

Ismail, R. (2012). Keberagamaan koruptor menurut psikologi. Esensia, XIII(2), 290-304. Mira. (2016). Pengaruh Self-assessment System dan Pemeriksaan Terhadap Tax 
Evasion Dengan Moralitas Pajak Sebagai Variabel Moderat Pada KPP Pratama Makassar Utara. Jurnal Ilmiah Akuntansi Peradaban, 2(1).

Mokhlis, S. (2009). Relevancy and Measurement of Religiosity in Consumer Behavior Research. International Business Research, 2(3), 75.

Purwanto, Sulaeha, T., \& Safira, H. (2018). Pengaruh Self Assessment System Dan Pemeriksaan Pajak Terhadap Tax Evasion (Studi Kasus Pada Wajib Pajak Badan Di Kantor Pelayanan Pajak Pratama Sumedang). Ekspansi, 10(2), 139-146. https:// doi.org/10.35313/ekspansi.v10i2.1206

Puspitasari, I., \& Wardani, D. K. (2013). Persepsi Wajib Pajak Orang Pribadi pada tingkat Kepatuhan Pelaksanaan Self-assessment System terhadap Tindakan Penyelundupan Pajak (Tax Evasion): Studi Pada KPP Pratama Sleman Yogyakarta. Jurnal Akuntansi, 1(2), 35-47.

Rahayu, S. K. (2013). Perpajakan Indonesia: Konsep dan Aspek Formal. Yogyakarta: Graha Ilmu.

Sari, T. M. (2015). Pengaruh Keadilan, Self Assessment System, Diskriminasi, Pemahaman Perpajakan, Pelayanan Aparat Pajak dan Kemngkinan Terdeteksi Kecurangan Terhadap Tindakan Tax Evasion. Accounting Analysis Journal.

Sekaran, U. (2006). Metodologi Penelitian Untuk Bisnis, (4th ed.). Jakarta: Salemba Empat.

Suwandhi, R. S. (2010). Persepsi Wajib Pajak Orang Pribadi Atas Pelaksanaan Self Assessment System Dalam Keterkaitannya Dengan Tindakan Tax Evasion (Studi Kantor Pelayanan Pajak Pratama Bandung Cibeunying). Digital Library UNIKOM.

Westbrook, K. W., Arendall, C. S., \& Padelford, W. M. (2011). Gender, Competitiveness, and Unethical Negotiation Strategies. Gender in Management, 26(4), 289-310.

Yunus, Y. N., Bulutoding, L., \& Umar, M. (2020). Pengaruh Pemahaman Perpajakan dan Self Assessment System Terhadap Tax Evasion dengan Iman Islam Sebagai Variabel Moderasi. ISAFIR: Islamic Accounting and ..., 1(2), 83-96. Retrieved from http://103.55.216.56/index.php/isafir/article/view/17691 